IZA DP No. 4713

Pay Enough, Don't Pay Too Much or Don't Pay at All? The Impact of Bonus Intensity on Job Satisfaction

Konstantinos Pouliakas

January 2010 


\title{
Pay Enough, Don't Pay Too Much or Don't Pay at All? The Impact of Bonus Intensity on Job Satisfaction
}

\author{
Konstantinos Pouliakas \\ CELMR, University of Aberdeen Business School \\ and IZA
}

\author{
Discussion Paper No. 4713 \\ January 2010
}

IZA

P.O. Box 7240

53072 Bonn

Germany

Phone: +49-228-3894-0

Fax: +49-228-3894-180

E-mail: iza@iza.org

Any opinions expressed here are those of the author(s) and not those of IZA. Research published in this series may include views on policy, but the institute itself takes no institutional policy positions.

The Institute for the Study of Labor (IZA) in Bonn is a local and virtual international research center and a place of communication between science, politics and business. IZA is an independent nonprofit organization supported by Deutsche Post Foundation. The center is associated with the University of Bonn and offers a stimulating research environment through its international network, workshops and conferences, data service, project support, research visits and doctoral program. IZA engages in (i) original and internationally competitive research in all fields of labor economics, (ii) development of policy concepts, and (iii) dissemination of research results and concepts to the interested public.

IZA Discussion Papers often represent preliminary work and are circulated to encourage discussion. Citation of such a paper should account for its provisional character. A revised version may be available directly from the author. 


\section{ABSTRACT \\ Pay Enough, Don't Pay Too Much or Don't Pay at All?
The Impact of Bonus Intensity on Job Satisfaction}

Using ten waves (1998-2007) of the British Household Panel Survey (BHPS), this paper investigates the ceteris paribus association between the intensity of incentive pay, the dynamic change in bonus status and the utility derived from work. After controlling for individual heterogeneity biases, it is shown that job utility rises only in response to 'generous' bonus payments, primarily in skilled, non-unionized, private sector jobs. Revoking a bonus from one year to the next is found to have a detrimental impact on employee utility, while job satisfaction tends to diminish over time as employees potentially adapt to bonuses. The findings are therefore consistent with previous experimental evidence, suggesting that employers wishing to motivate their staff should indeed "pay enough or don't pay at all".

\section{NON-TECHNICAL SUMMARY}

This paper examines the effect of the intensity of financial incentives (i.e. the proportion of workers' salary that is tied to bonuses) on the job satisfaction of British employees. Using ten years of data (1998-2007) from the British Household Panel Survey (BHPS), it takes into account recent evidence from psychological and economic experiments suggesting that the magnitude of incentive payments by employers may play an important role in terms of motivating workers. Specifically, it has been shown that relatively "small" payments of bonuses may have a negative effect on the satisfaction that workers derive from their jobs, while only "large" bonuses are likely to make employees exert more effort. In this study it is confirmed that job satisfaction rises in response to bonus payments as long as these are "large" enough. This is found to be particularly the case for male workers in skilled, nonunionized private sector jobs. Evidence is also presented that workers are likely to experience a significant drop in their satisfaction if a bonus is retrieved even though it was offered in the previous year. Furthermore, it is also found that individuals tend to get accustomed or adapt to the payment of bonuses over consecutive years. The findings of this research suggest that caution should be exercised by employers in their decision whether to introduce a 'small' monetary incentive in the first place. In addition, firms should be wary of the potentially weakening or insignificant influence that the payment of bonuses may have on job satisfaction and, hence, employee performance over time.

JEL Classification: $\quad$ C23, J28, J33, M52, M54

Keywords: incentives, intensity, bonus, performance pay, job satisfaction

Corresponding author:

Konstantinos Pouliakas

Department of Economics

University of Aberdeen Business School

\& Centre for European Labour Market Research

Edward Wright Building

Dunbar Street

Old Aberdeen AB24 3QY

United Kingdom

E-mail: k.pouliakas@abdn.ac.uk

\footnotetext{
* The author would like to thank I. Theodossiou, G. Panos and two anonymous referees for helpful comments and assistance during the preparation of this manuscript. The usual disclaimer applies.
} 


\section{INTRODUCTION}

The principal-agent model, with its convincing illustration of the trade-off that arises between risk and incentive provision when attempting to align the conflicting interests of two contracting parties, remains central for our understanding of the compensation strategies employed by firms (Mirlees, 1976; Holmstrom, 1979). According to the standard model of agency theory, the introduction of financial incentives as part of an agent's remuneration package will increase his/her productivity, as it is assumed that individuals derive utility from income whilst the exertion of effort entails a utility cost. Importantly, if the additional disutility of higher effort is compensated by an adequate wage premium, an implication of the theory is that the marginal utilities of workers under fixed and variable compensation schemes should be equalized in the long-run. What this implies is that there should be no difference between the job satisfaction of employees receiving monetary incentives and those on non-contingent payment arrangements.

The above conclusion has been disputed by a psychological (and, increasingly, economics) literature, which has stressed that the incorporation of non-pecuniary motives into the economic paradigm, such as the desire for reciprocation or for engaging in interesting tasks, has important implications for an individual's motivation and job satisfaction (Deci, 1971; Deci and Ryan, 1985; Kreps, 1997; Frey, 1997; Frey and Jegen, 2001). In addition, it has been argued that 'wrong' monetary incentives may incite dysfunctional behavioural responses by employees (Holmstrom and Milgrom, 1991; Baker, 1992; Prendergast, 1999), or have a detrimental effect on employee morale and job security via the inequitable and risky pay distributions that arise as a consequence (Baker et al., 1988).

Once these mechanisms are taken into consideration, it becomes clear that the theoretical impact of monetary incentives on worker effort and job satisfaction can be ambiguous. As corroborated in a number of economic experiments (Falk and Kosfeld, 2006; Eriksson and Villeval, 2008), the incentive effects of monetary rewards are likely to be compromised in a world of imperfect labour mobility populated by heterogeneous agents with varying psychological dispositions. To the extent that incentive schemes allow for optimization of effort, facilitate worker autonomy and enhance self-determination they should increase job satisfaction, other things equal. Yet increasing earnings risk, crowding out of the inherent pleasantness in performing one's job and lower morale can lead to disgruntled employees.

The study of the effect of monetary rewards on job satisfaction is therefore an empirical issue, which has only until recently received any attention. In particular, a number of studies have shown that in Britain bonuses result in higher job satisfaction, although the effect of individual-based performancerelated pay (PRP) systems is not as clear-cut once unobserved heterogeneity is taken into account (Drago et al., 1992; McCausland et al., 2005, Artz, 2008, Green and Heywood, 2008; Pouliakas and Theodossiou, 2009). Using US data, Heywood and Wei (2006) have also confirmed that all types of PRP (bar piecerates) yield greater job satisfaction relative to time rates. 
A potential deficiency of the above-mentioned studies is that they only focus on the discrete difference in job satisfaction between workers receiving PRP and those on alternative schemes. Thus, they ignore the fact that worker performance and satisfaction may vary according to the magnitude of incentives. As suggested by a series of field experiments performed by Gneezy and Rustichini (2000[a], p. 802), "for all positive but small enough compensations, there is a reduction in performance as compared with the zero compensation, or, better, with the lack of any mention of compensation". Nevertheless, once the extrinsic motivation is large enough, it results in better performance than in the noincentive case. This non-monotonicity in the reaction of worker effort to both positive and negative incentives (e.g. bonuses or fines, respectively) has consequently been termed the "W effect" of incentives (Gneezy, 2004). ${ }^{1}$ By contrast, the recent experimental study of Pokorny (2008) finds an inverse U-shaped relationship between effort levels and incentive intensity.

This paper attempts to test the above contrasting hypotheses by looking beyond the mere incidence of incentive pay and examining the impact of the intensity of incentives (i.e. the proportion of workers' salary that is tied to bonuses) on job satisfaction instead. Specifically, 10 waves (1998-2007) of the British Household Panel Survey (BHPS) are used to investigate the association between the power of bonus payments and the utility derived from work, holding the incidence of individual-based PRP and other important determinants constant. After controlling for individual fixed effects (such as ability or motivation) that may bias the influence of payment schemes on job satisfaction, job utility is found to rise only in response to 'large' bonus payments. Evidence is also presented that revoking a bonus from one year to the next is likely to have a detrimental effect on employee utility, and that over time job satisfaction tends to diminish as employees potentially adapt to the payment of bonuses. The empirical evidence of the paper is therefore consistent with Gneezy and Rustichini's (2000[a]) assertion that employers wishing to motivate their staff should indeed "pay enough or don't pay at all".

The structure of the paper is as follows. Section 2 engages in a review of the available literature on the effect of financial incentives on job satisfaction. In Section 3 the data used in the study are described and preliminary statistical correlations are outlined. Section 4 describes the basic econometric methodology used in the paper. Section 5 outlines the main empirical results of the relationship between incentive intensity and the utility derived from employment. Section 6 examines the heterogeneity in the sample further. Finally, Section 7 concludes.

\section{LITERATURE REVIEW: THE IMPACT OF INCENTIVE PAY ON JOB SATISFACTION}

The growing economics literature on subjective well-being (Clark and Oswald, 1996; Clark, 1999; Blanchflower and Oswald, 2004; Van Praag and Ferrer-i-Carbonell, 2004; EPICURUS, 2007) has emphasized that measures of job satisfaction are significant predictors of employee behaviour (e.g. quits (Freeman, 1978), absenteeism (Clegg, 1983) or worker productivity (Judge et al., 2001)). It follows that 
understanding the influence of monetary incentives on job satisfaction is important given that the composition of an employee's remuneration package is an integral element of his/her overall working conditions.

The fact that firms typically employ a wide array of incentive instruments has been attributed to the fundamental agency problem that plagues the employment relationship (Gibbons and Waldman, 1999). In order to combat the problem of moral hazard, firms design incentive contracts that seek to achieve goal congruence with their employees (Mirlees, 1976; Holmstrom, 1979). ${ }^{2}$ Furthermore, as shown by Lazear $(1986,2000)$, the introduction of financial rewards should induce more highly geared workers to put forth extra effort to the point where the marginal value added equates the marginal cost of the additional labour. ${ }^{3}$ In long-run equilibrium, however, one would not expect to observe any differences in the marginal utilities of comparable workers under fixed or variable payment schemes, as the expected value of the higher wages paid under PRP should be just sufficient to compensate for the additional earnings risk and the disutility of extra effort (Mas-Colell et al., 1995).

Once the standard assumptions of the agency model are relaxed, though, there are many reasons to expect that PRP is likely to have a non-negligible impact on job satisfaction. Expectancy-based theories of organizational psychology have asserted that attitudes about work are shaped from the rewards produced by performance (Lawler and Porter, 1967), which are valued outcomes in themselves (Judge et al., 2001, p. 378; Brown and Sessions, 2003). ${ }^{4}$ Furthermore, it has been argued that PRP is an integral element of so-called 'high performance workplace practices', which have been found to be positively related to job satisfaction (Bauer, 2004).

Other aspects of PRP may, nonetheless, diminish productivity and worker satisfaction. It has been illustrated that wrongly devised compensation schemes can have counterproductive consequences, as they may encourage workers to 'game' the compensation system to their advantage by multitasking (Baker, 1992) or by engaging in rent-seeking behaviour aimed at influencing the subjective evaluations of line managers (Prendergast, 1999). Holmstrom's (1982) seminal paper has also showed that utilizing team production incentive schemes (such as profit-sharing) may dilute individual performance as a result of free-riding. In the face of evidence suggesting that the job satisfaction of employees is intrinsically linked to their relative pay status (Clark and Oswald, 1996; Clark, 1999; Ferrer-i-Carbonell, 2005; Clark et al., 2008[a]), the demoralising dispersion and variability in wages that ensues from PRP schemes is also likely to affect attitudes to work in a negative fashion. Furthermore, it has often been claimed that financial incentives undermine collaboration and team work, emphasize the power asymmetry between management and the workforce, and reduce employee risk-taking and innovation (Kohn, 1993).

Added to the above is a prominent non-economic criticism of PRP which is based on the so-called cognitive evaluation or motivation crowding-out hypothesis (Deci and Ryan, 1985; Frey and Jegen, 2001). According to this theory of social psychology, once it is acknowledged that individuals may derive intrinsic satisfaction from their jobs, explicit rewards that are perceived as controlling devices or 
as indicators that the employment relationship is a pure market exchange (Kreps, 1997, p. 363), are likely to compromise job satisfaction and performance. In fact, there are now a number of experimental studies indicating that financial incentives may backfire by acting as a signal of employer distrust (Falk and Kosfeld, 2006) or by undermining reciprocity-based voluntary cooperation (Fehr and Gachter, 1998).

Only until recently did the economic literature pay any attention to the study of which of the aforementioned effects of PRP on job utility predominates. Drago et al. (1992) and McCausland et al. (2005) were among the first to contrast the satisfaction of employees receiving PRP with those on alternative arrangements. The latter find that PRP may have demotivating consequences for the lowerpaid segment of the population (after correcting for potential selectivity bias). Heywood and Wei's (2006) analysis shows that profit sharing and PRP are associated with higher overall job satisfaction in the US, though they find evidence that piece rates in particular may have a negative effect. More recently, Green and Heywood (2008) and Pouliakas and Theodossiou (2009) use the BHPS to investigate the impact of PRP on a fuller set of facets of job satisfaction. They show that although bonuses and profit-sharing schemes result in higher mean job satisfaction, the effect of individual-specific PRP diminishes once unobserved heterogeneity is taken into account. They also fail to find any supporting evidence in favour of arguments that PRP crowds-out the intrinsic satisfaction of jobs or has an adverse impact on job security. Artz (2008), on the other hand, argues that, on the net, PRP increases job satisfaction but does so largely among union workers and males in larger firms.

The above studies focus merely on the impact of the incidence of PRP on job satisfaction. This masks the possibility that the utility of workers may vary according to the magnitude and intensity of incentives, as suggested by the experiments of Gneezy and Rustichini (2000[a][b]). In these experiments, the effect of the introduction of a monetary reward and the differential impact of small and large payoffs is tested on the performance of students from Israel. The evidence indicates that "the effect of monetary incentives can be, in small amounts, detrimental to performance" and that there is "a discontinuity at the zero payment of the effect of monetary incentives" (ibid., p. 801-802). ${ }^{5}$

An important common element of the above experiments is that "small" incentives are likely to exert a negative effect on behaviour (with discontinuity close to zero), while for high powered rewards (or punishments) the standard price effect is expected to prevail. ${ }^{6}$ This prediction has been corroborated in the proposer-respondent game experiment of Gneezy (2004), which ultimately gives rise to a (V)Wshaped relationship between effort and the intensity of (positive) incentives. In contrast, the IQ and counting tasks experiments performed by Pokorny (2008) on undergraduate German students indicate an inverse U-shaped relationship between effort levels and the strength of monetary payoffs. The author attributes her contradicting findings to the existence of reference dependent preferences among subjects, which imply decreasing effort choices with stronger incentives once a reference income level is exceeded. Another example of the non-monotonic motivation effect of incentives can be found in the field study of Marsden et al. (2001), who highlight that although a large number of workers in their sample experienced 
a deterioration of workplace relations and cooperation following the introduction of incentive pay, PRP motivated those who received above average payments.

The remainder of the paper now turns to an investigation of which of the aforementioned contrasting patterns, as depicted in Figure 1, are likely to describe the association between job satisfaction and the intensity of monetary rewards received by British employees.

\section{[INSERT FIGURE 1 ABOUT HERE]}

\section{DATA AND DESCRIPTIVE STATISTICS}

The study uses data from waves 8 to 17 (1998-2007) of the British Household Panel Survey (BHPS), as readily available information on individual-based PRP is only available for those years, while the survey question clarifying the amount of bonus pay was asked from 1997 onwards. The BHPS is a nationally representative survey that each year interviews a random sample of nearly 10,000 individuals in approximately 5,500 British households. It has been conducted annually since late 1991 and contains a wealth of information on employees' personal and employment characteristics. The sample used in the paper is restricted to individuals between 18 and 65 years of age who are paid employees at the survey date. For 10 waves of the BHPS this yields an unbalanced panel of 67,535 observations on 14,479 unique individuals.

A sizeable portion of this sample (25.77\% corresponding to 17,372 observations) has replied affirmatively to the question: "In the last 12 months have you received any bonuses such as a Christmas or quarterly bonus, profit-related pay or profit sharing bonus, or an occasional commission? This excludes overtime payments". ${ }^{7}$ Beginning from wave 7 , the above subset of individuals are also asked to state in a follow-up question the exact amount of bonus/profit-sharing they received in the previous year, and whether this amount is gross or net of taxes. Finally, in order to capture the presence of pay incentives that are based on individual employee performance only, the BHPS has asked since 1998 the question "Does your pay include performance related pay"?. Approximately 14\% of the sample responded that they are indeed recipients of such a form of compensation. ${ }^{8}$

Focussing on the non-missing responses regarding the amount of bonus/profit-sharing received, the answers of $7 \%$ of the sample $(4,849$ out of a total of 17,372 observations) who provided a post-tax figure were initially converted into a gross amount. This was done by utilizing the available information on the gross and take-home pay (at the last payment) of the respondents, subsequently calculating the rate with which the net bonus figures should be multiplied in order to be converted into a gross amount. In addition, in order to neutralize the effect of outliers, the bonus variable was top-coded at the $99^{\text {th }}$ percentile of its distribution (corresponding to an annual bonus payment of $£ 31 \mathrm{k}$ ). After engaging in the above manipulations, the individuals in the sample are found to receive average bonus/profit-sharing 
payments of $£ 1684$ per annum. This corresponds to approximately $6.7 \%$ of their average yearly gross usual earnings.

Table 1 provides a break-down of the mean amount of bonus received by various demographic and socio-economic groups of the sample, along with the respective incentive intensity. The latter is defined as the proportion of the respondents' usual gross yearly earnings that is tied to the payment of bonuses. It is evident that men receive higher bonus/profit-sharing payments on average relative to women, while an inverse U-shaped age effect is apparent. Individuals who are married and more educated are also recipients of higher incentive rewards. With respect to working conditions, full-time employees who work in the private sector, on permanent contracts and in non-union jobs are found to enjoy greater bonuses. Finally, the receipt of individual-based PRP, firm size and the type of occupation also play an important role in determining the amount of reward, with managers and professionals benefiting the most.

\section{[INSERT TABLE 1 ABOUT HERE]}

Following the rating of various partial job satisfactions (e.g. promotion prospects, total pay, relations with supervisors, job security, ability to work on own initiative, the actual work itself and hours of work), individuals in the BHPS are asked a question regarding their overall job satisfaction, worded as follows: "All things considered, how satisfied or dissatisfied are you with your present job overall using the same 1-7 scale?". Answers are evaluated on a seven point scale, where a value of one corresponds to 'not satisfied at all' and seven reflects 'complete satisfaction'. These job satisfaction responses are employed in this study to identify the determinants of the utility of employment as perceived by the individual workers themselves.

Table 2 shows how the mean values of job satisfaction vary depending on the type of incentive pay provided and the incentive intensity. It is interesting that average job satisfaction varies in a V-type fashion with the intensity of bonus/profit-sharing pay received by employees. It initially falls from a value of 5.37, when no bonus rewards are present, to 5.32 for those who receive bonuses equivalent to 1$3 \%$ of their total remuneration. Job satisfaction subsequently rises at above average rewards, exhibiting a marked increase for workers at the top 5\% of the bonus ladder (5.47).

\section{[INSERT TABLE 2 ABOUT HERE]}

Table A1 in the Appendix also presents some descriptive statistics on a number of other important explanatory variables, which are expected to influence job satisfaction. These factors constitute a standard control set in the job satisfaction literature, and have been specifically chosen to be consistent with those used in Green and Heywood (2008) and Pouliakas and Theodossiou (2009).

\section{ECONOMETRIC METHODOLOGY}


In the remaining part of the paper a multivariate regression methodology is employed in order to uncover the true ceteris paribus influence of the explanatory variables on job satisfaction. The empirical framework that is employed assumes that (either partial or overall) job satisfaction $(J S)$ of individual $i(i=$ $1, \ldots, N)$ in time period $t(t=1, \ldots, 10)$ is a function of a variety of individual and job characteristics:

$$
J S_{i t}=\alpha_{1}+\alpha_{2} \mathbf{I}_{i t}+\alpha_{3} \mathbf{X}_{i t}+\alpha_{4} \mathbf{T}_{t}+u_{i t}
$$

where $\mathbf{X}$ is a vector of individual and employment variables assumed to influence JS (inclusive of the incidence of individual-based PRP), $\mathbf{T}$ is a vector of yearly dummy variables capturing the presence of fixed time effects (such as changing technologies or shifting managerial styles, both of which could potentially affect the relationship between bonuses and $J S$ ), the $\alpha$ 's are associated coefficients, and $u_{i t}$ is a randomly distributed error term with $\mathrm{E}(\mathbf{u})=0$ and $E\left(\mathbf{u u}^{\prime}\right)=\sigma_{u}^{2}$. The main independent regressor $\mathbf{I}$ is a variable denoting the incentive intensity of employees' annual remuneration, $I^{*}$, as follows:

$$
I=\left\{\begin{array}{lll}
I^{*} & \text { if } & B_{S}=1 \\
0 & \text { if } & B_{S}=0
\end{array}\right.
$$

where $B_{s}$ is the endogenously determined selection variable that denotes whether individual workers have received a bonus or not:

$$
B_{S}=\left\{\begin{array}{lll}
1 & \text { if } & B_{s}^{*}>0 \\
0 & \text { if } & B_{S}^{*} \leq 0
\end{array}\right.
$$

Using $\mathbf{I}$ as the main explanatory variable in the specification, as opposed to including the amount of bonus, $B$, or the absolute level of pay, $W$, as separate variables, takes into account the fact that agency theory is primarily concerned with the optimal determination of I. It also reflects the fact that $W$ and $B$ are likely to be simultaneously set by employers. Estimation of their separate influence on job satisfaction is therefore likely to be fraught by endogeneity bias. Of course, (1) neglects the fact that the inherent level of risk to which employees of a similar level of $\mathbf{I}$ are exposed to may differ according to their underlying level of wealth. For this reason, particular attention has been paid so that the control set includes both objective and subjective variables which accurately describe the financial situation of the respondents, such as their household income.

One way of estimating the above system is by regressing the dependent $J S$ variable against $\mathbf{I}$, using only the sample of individuals that are recipients of positive monetary incentives $\left(B_{s}=1\right)$. Such a course of action gives rise to the potential of selectivity bias, and hence requires a Heckman-type estimator (Heckman, 1979; McCausland et al., 2005). The latter procedure is reliant on the presence of appropriate 
identifying variables, $\mathbf{Z}$, in the selection equation, which describes the likelihood of individuals being recipients of incentive pay:

$$
B_{\text {sit }}=\gamma_{1}+\gamma_{2} \mathbf{Z}_{i t}+\gamma_{3} \mathbf{T}_{t}+\phi_{i t}
$$

where $\varphi$ is the error term and $\gamma$ are associated regression coefficients.

Nevertheless, in order to test Gneezy's (2004) suggestion that there is discontinuity close to the zero payoff in the effect of monetary rewards on job performance, as well as the evidence of Marsden et al. (2001) that only above average incentives are beneficial, the preferred specification in this paper involves the estimation of equation (1) on the full sample of workers, using a series of indicator variables $\mathbf{I}_{\mathrm{d}}$, as regressors:

$$
J S_{i t}=\alpha_{1}+\alpha_{2} \mathbf{I}_{d i t}+\alpha_{3} \mathbf{X}_{i t}+\alpha_{4} \mathbf{T}_{t}+u_{i t}
$$

where $d$ refers to the $0,5^{\text {th }}, 25^{\text {th }}, 50^{\text {th }}, 75^{\text {th }}$ and $95^{\text {th }}$ percentiles of the frequency distribution of the variable I. The main regressors of interest are therefore a series of dummy variables that distinguish individuals according to whether the proportion of their annual earnings that is linked to bonus pay is $0 \%$ (reference category), less than $1 \%$, between $1-3 \%, 3-8 \%, 8-25 \%$ and above $25 \%$, respectively.

Given the ordered categorical nature of the dependent variable, $J S$, estimation of equation (5) is conventionally implemented using an ordered probit (OP) estimator (McKelvey and Zavoina, 1975). However, the empirical strategy also takes into account the fact that an OP procedure is likely to reveal a distorted effect of $\mathbf{I}_{\mathrm{d}}$ on $J S$, given the presence of unobserved heterogeneity among the employees of the sample. Specifically, it is reasonable to believe on the grounds of agency theory that bonus payments are likely to be higher for those individuals who are less risk-averse, more extrinsically motivated and for whom the cost of effort is less dear (Lazear, 1986). Given that these individual attributes, which are likely to be correlated with both $\mathbf{I}_{\mathrm{d}}$ and $J S$, are unobserved to the survey statistician, it follows that a simple OP regression of (5) might lead to inconsistent estimates. This is also likely to be true given that the analysis can only control for a limited set of firm characteristics, which is a notable deficiency given that the latter are likely to be endogenously related to wage schemes. It is therefore necessary to estimate (5) using a fixed effects model of panel analysis (Wooldridge, 2002). As is standard, the idiosyncratic disturbance term $u_{i t}$ is split into the time-invariant fixed individual effect, $\varepsilon_{i}$, and a pure random error term, $\eta_{i t}$, with $E\left(\eta_{i t}\right)=0$ and $E\left(\varepsilon_{i}, \eta_{i t}\right)=0$, as follows:

$$
J S_{i t}=\alpha_{1}+\alpha_{2} I_{d i t}+\alpha_{3} \mathbf{X}_{i t}+\alpha_{4} \mathbf{T}_{t}+\varepsilon_{i}+\eta_{i t}
$$

Given that with the estimation of equation (6) the influence of any fixed individual effects is controlled for, it is hence expected that the 'true' influence of $\mathbf{I}_{\mathrm{d}}$ on job satisfaction will be uncovered. 


\section{EMPIRICAL RESULTS AND SENSITIVITY ANALYSIS}

\subsection{Ordered probit estimates of the effect of bonus intensity on job satisfaction}

From the regression output in Table 3 interesting insights regarding the impact of incentive pay on job utility are drawn. ${ }^{10}$ According to the predictions of previous studies, the incidence of bonus pay is associated with a significantly higher level of overall job satisfaction. The OP estimates of Column (1) in Table 3 illustrate further that this effect is magnified as the intensity of rewards increase, though no significant effect is found for small bonuses that account for less than $1 \%$ of employees' salary. Indeed, in terms of the economic significance of the estimates it is calculated that as the intensity of incentives increases, the probability of reporting the highest possible score on the satisfaction scale (i.e. 7) rises by approximately $1 \%$ at the mean (relative to those who do not receive incentive wages). This likelihood rises to as much as $4 \%$ for those at the top $5 \%$ of the ladder of rewards, which is one of the most pronounced impacts that any of the explanatory variables in the model have on job satisfaction.

\section{[INSERT TABLE 3 ABOUT HERE]}

In order to scrutinize the effect of the bonus intensity variable further, the analysis is replicated by omitting from the sample employees who receive individual PRP. This is done since the BHPS does not contain information on the proportion of workers' salary that is exposed to PRP. Such a deficiency may confound the main estimates, given that it is likely that the respondents who were in simultaneous receipt of bonuses and PRP may have not separated the two when answering the amount of bonus question in the questionnaire. Indeed, it is clear from the data that the incentive intensity of those workers who received both types of reward is higher compared to those who declared that they were in receipt of bonuses only (9\% vs. 5.7\%, respectively). Reassuringly, once the individuals receiving PRP are ignored, a slightly stronger significant effect of bonus intensity on job satisfaction is found, as can be seen in Table A2 (Column 1) in the Appendix.

To test the robustness of the bonus coefficient further, the regression of equation (5) is performed using a more detailed occupational classification than before. Since the offer of bonus pay occurs more frequently in certain occupations (for example, larger bonuses are more common in the financial sector), the use of detailed occupational controls may capture the variation in incentive pay across workers in a more accurate fashion. As is confirmed in Table A2 (Column 2), the effect of the bonus intensity variables remains robust to the inclusion of two-digit occupational dummy variables in the specification, with even the lowest intensity category now having a significant effect.

The main regression has also been repeated after retaining only the sample of respondents who provided a before-tax figure of the amount of bonus awarded. This is done in order to examine the sensitivity of the results to the conversion of the after-tax bonus data to gross amounts, as discussed in 
section 3. Reassuringly, the robustness of the positive effect of higher bonus intensity on job satisfaction is confirmed (Column 3 Table A2).

It is important to notice that the positive relationship between job satisfaction and incentive intensity is found even after including various measures of reference dependent earnings within the control set (see Column 4 of Table A2), such as the comparison level of bonuses received by 'comparable' workers each year (Clark and Oswald, 1996), or the prior (Clark, 1999) and posterior (Chevalier and Lydon, 2002) financial comparisons of an individual with his/her past and future financial situation, respectively. This casts doubt on the assertion that job utility increases with incentives only when individual wages have not surpassed a given reference point, as would be the suggestion of the Pokorny (2008) model.

Finally, it may be argued that the magnitude of the bonus payments to workers, and hence their degree of job satisfaction, may be directly dependent on the economic conditions faced by firms, which will determine whether they have a good or a bad fiscal year. Given that information on the financial situation of the individual firms offering incentive pay is not available, the main regression has been executed by including the regional unemployment rate as a proxy for the demand conditions prevailing in the economy in a particular year. The addition of this variable in the specification, along with the time fixed effects, is believed to capture some of the variability in job satisfaction scores that is related to shifting economic conditions over time. As shown in Column (5) of Table A2, the effect of the bonus dummies remains unaffected.

\subsection{Correcting for unobserved heterogeneity bias}

As discussed in section 3, the omission of important variables from the specification is likely to bias the coefficients of the incentive variables. In general, the magnitude of bonus wages is not only a function of employee characteristics, but also depends on whether firms place a high or a low 'gearing' on performance. To the extent that some of these unobserved factors are time-invariant, a fixed-effects estimation of equation (6) is therefore likely to provide a more consistent estimate of the influence of varying bonus intensity on job satisfaction. ${ }^{11}$

Following the removal of unmeasured effects, the positive effect of bonuses on job satisfaction is found to be pronounced (and statistically significant) only for individuals at the top $25 \%$ of the ladder of rewards (see Column 3 of Table 3). These results are hence indicative of the presence of unobserved person- or job-specific characteristics, which are correlated with both performance-contingent modes of pay and the job satisfaction scores.

\subsection{Correcting for selectivity bias of incentive pay}

In order to detect the marginal effect of an increase in bonus intensity on job satisfaction, Heckman's consistent two-step estimator is also employed after restricting the sample to include only those workers 
who are in receipt of bonuses (excluding PRP as described above). This entails the estimation of the selection equation (4) as a first stage, which identifies the probability of individuals being offered a bonus (see Column 4 of Table A3 in the Appendix). Identification is achieved via the inclusion of an additional variable, namely whether the pay slip of individuals was seen by the interviewer at the time of the survey. This is confirmed to be exogenous to the job satisfaction process, yet significantly related to the incidence of bonus pay as stated by the respondents. It is believed that this variable is found to be statistically related to the incidence of bonus pay (at the $1 \%$ level of significance) given that the exhibition of the pay slip is likely to have minimized the potential for recall bias on behalf of the interviewees.

Following the above procedure, job satisfaction is regressed on a continuous measure of bonus intensity (Proportion). ${ }^{12}$ No evidence of selectivity bias is detected, as evidenced by the insignificant mills ratio term in Column (4) of Table 3. Furthermore, it is found that a $1 \%$ increase in the proportion of workers' compensation that is tied to bonuses is found to increase their job satisfaction rating by 0.004 points, which is equivalent to an marginal increase of $5 \%(0.004 / 7 * 100)$ in utility.

\subsection{Comparing like with like: examining an alternative counterfactual}

As opposed to comparing the utility of workers who are paid a non-variable wage with those receiving bonuses, one can examine an alternative counterfactual which allows for a more accurate evaluation of the impact of varying amounts of bonuses across individuals who are more 'alike'. This involves the ceteris paribus contrast of job satisfaction between employees who are paid by PRP but not bonuses (the reference category), with those who are recipients only of bonuses (but not PRP). Given that in this case the focus is exclusively on those in receipt of incentive pay, it is expected that the aforementioned comparison is between workers who possess more 'similar' characteristics. Of course, in order implement such an exercise a Heckman-type strategy is required, as in section 5.3 above, that takes into account the selectivity bias of focusing on individuals who are given incentive rewards. The results of this estimation are presented in Table 3 (Column 5), where it is evident that a significant positive impact is found only for those individuals receiving more than $25 \%$ of their pay in bonuses.

\section{FURTHER ANALYSIS}

\subsection{Effect of bonus intensity on satisfaction with facets of jobs}

In order to obtain a deeper understanding of the effect of bonus intensity on job satisfaction, equation (6) has been regressed using the facets of job satisfaction that are available in the BHPS as dependent variables. The estimated coefficients are depicted in Table 4, whereby it is evident that higher financial incentives increase workers' satisfaction with their total pay and job security, without having any significant adverse impact on satisfaction with their hours of work. An interesting result, however, is that 
smaller bonus rewards are found to exert a significant negative effect on the satisfaction that employees derive from the actual work itself. To the extent that the latter constitutes a proxy for the intrinsic motivation of individuals, this significant negative association provides some evidence that the so-called crowding-out hypothesis may be related to the magnitude of the financial reward, as suggested by Gneezy and Rustichini (2000[a]).

\section{[INSERT TABLE 4 ABOUT HERE]}

\subsection{Effect of bonus intensity by key characteristics}

Significant heterogeneity in the effect of bonus intensity on job satisfaction is found for various subgroups of the population. While Heywood and Green (2008) and Artz (2008) argue that bonuses and profit-sharing schemes seem to be more beneficial for men rather than women on average, Table 5 illustrates that this finding is driven by the greater job satisfaction of male employees at the highest segment of the bonus distribution only.

The former authors also present evidence that the offer of bonuses is likely to have a differential impact on the job satisfaction of union and non-union employees. Nevertheless, it is revealed in Table 5 that only the satisfaction of non-union workers whose compensation is at the upper tails of the bonus distribution is likely to be affected. No effect, in contrast, is found in the satisfaction of unionized employees.

It has often been argued that in certain organisational environments where intrinsic work motivation is high (e.g. public sector jobs), the need for incentive pay is reduced and different pay arrangements need to be designed instead (Burgess and Rato, 2003). Furthermore, it has been asserted that individuals who are employed in unskilled manual occupations might suffer from a greater inability to diversify the additional risk that is inherent in the variability of incentive schemes, relative to those who are at the top of the income distribution (McCausland et al., 2005). The coefficients in Table 5 provide some support to these hypotheses, as they indicate that 'large' bonus outlays are only likely to enhance the job satisfaction of private sector employees who are employed in skilled occupations.

The above analysis therefore suggests that relatively generous bonuses are likely to have a prominent impact on the job satisfaction of male, skilled employees who are employed in private sector jobs and whose workplace is not covered by a trade union arrangement.

\section{[INSERT TABLE 5 ABOUT HERE]}

\subsection{Effect of dynamic changes in bonus status on job satisfaction}

Apart from emphasizing that employers must pay considerably large bonuses in order to motivate workers, Gneezy and Rustichini (2000[a]) also assert that the introduction of a monetary incentive is likely to alter the nature of an incomplete contract. For instance, if workers had previously engaged in 
certain job tasks without compensation, once the employer associates those activities with the payment of bonuses the perception of the contract now changes, with the employee "expecting" to be paid for the execution of those tasks in the future. Crucially, what this implies is that "the change in perception, once realized, is hard to reverse" (ibid, 2000, p. 804), so that one would expect that the fall in motivation once a reward is revoked will be larger than the original gain in satisfaction following the introduction of an incentive bonus.

Evidence in favour of this assertion is provided by the raw statistics in the dataset, as it is found that the average job satisfaction of workers switching from no bonus payments to positive ones is greater than of those moving in the reverse direction (5.33 versus 5.24, respectively). Examining this issue further using a multivariate fixed effects regression approach, interesting findings arise when looking at the job satisfaction of workers who have experienced a change in the incidence of bonus pay. Specifically, as can be seen from Table 6, Gneezy and Rustichini's (2000[a]) claim is confirmed, as there is a significantly lower level of job satisfaction experienced by individuals who move from having a bonus in one year to not receiving it in the following year (relative to those who are not paid a bonus continuously throughout time). In contrast, the utility from work rises for employees who receive a bonus even though they did not do so in the previous year, though the increase in satisfaction is not significant relative to the reference group.

Another interesting implication of the analysis is that employees who receive bonuses for a number of consecutive years experience a lower mean level of job satisfaction, relative to those who do not receive such contingent pay over time. This can potentially be explained on the basis of adaptation of workers to their compensation, given that, as most managers would attest to, individuals tend to get accustomed to a given level of pay (Lawler, 1971; Georgellis et al., 2008; Pouliakas and Theodossiou, 2010). To further understand the dynamics of the adaptation process, the "leads and lags" methodology of Clark et al. (2008[b]) and Georgellis and Tabvuma (2010) has thus been adopted, whereby workers are identified according to the number of years that they consecutively receive a bonus since their initial change in payment status. The following regression equation has therefore been estimated:

$$
J S_{i t}=\alpha_{1}+\beta \mathbf{X}_{i t}+\theta_{0} B_{0 i t}+\theta_{1} B_{1 i t}+\theta_{2} B_{2 i t}+\theta_{3} B_{3 i t}+\theta_{4} B_{4 i t}+\theta_{5} B_{5 i t}+\theta_{6} B_{6 i t}+\varepsilon_{i t}
$$

where $B_{0 \mathrm{it}}=1$, captures individuals currently in receipt of a bonus even though they were not paid as such in the previous year (i.e. $\mathrm{B}_{\mathrm{t}}=1$ but $\mathrm{B}_{\mathrm{t}-1} \neq 1$ ). Similarly, being offered a bonus for one to two years, $B_{1 \mathrm{it}}=1$, is identified as $\mathrm{B}_{\mathrm{t}}=1, \mathrm{~B}_{\mathrm{t}-1}=1$ and $\mathrm{B}_{\mathrm{t}-2} \neq 1$, and so on for longer lags. The last category, $B_{6 \mathrm{it}}$, is a catch all dummy for those individuals that have received a bonus for more than 5 years continuously.

A fixed effects estimator is employed in order to account for the fact that unobserved characteristics may be associated with the propensity of individuals to move across different states. Based on the estimation of equation (7), negative coefficients are found for those individuals who continue to get paid 
by bonuses after the initial switch in status. However, the fall in job satisfaction is significant only for those who have received incentive pay for four consecutive years.

\section{[INSERT TABLE 6 ABOUT HERE]}

\section{CONCLUDING REMARKS}

The findings of this paper provide support to experimental evidence that monetary incentives may have a positive effect on workers' utility and performance as long as they are large enough. All other things equal, a higher intensity of rewards is observed to enhance the utility that workers derive from their jobs. These conclusions hold even after controlling for the effect of unobserved heterogeneous biases that confound the incentives-job satisfaction relationship.

Nevertheless, the significant negative association between 'small' bonus payments and the satisfaction of workers with the actual job itself, along with evidence that the retrieval of a bonus may have a deleterious effect on job satisfaction after this has been already paid, draws attention to the fact that caution should be exercised by employers in their decision whether to introduce a 'small' monetary incentive in the first place. In addition, firms should be wary of the potentially weakening or insignificant influence that the payment of bonuses may have on job satisfaction over time. Once introduced, though, the findings of this paper suggest that "generous" rewards are more likely to foster positive attitudes towards work among male employees who work in skilled occupations within the non-unionized private sector of the economy.

Future research should attempt to augment the empirical specification of this study with the inclusion of an enlarged set of firm characteristics, so that more precise estimates are obtained. In particular, a matched employer-employee dataset would allow for a more accurate evaluation of the effect of incentive intensity on employee satisfaction, since this would permit observation of the type of workers that are recipients of bonus pay, along with identification of the provision of PRP systems within their specific firms. One can envisage, for example, that the negative effect of no incentive payments on job satisfaction will be more pronounced for employees who work in organizations that offer bonuses to their co-workers but not to themselves. Unfortunately, although matched employer-employee datasets exist in the UK context, to the author's knowledge none of them contain at present information about the amount of incentive pay received by workers. 


\section{References}

Artz, B, (2008), Firm Size, Performance Pay and Job Satisfaction, Labour, 2(2): 315-343.

Baker, G.P. (1992), Incentive Contracts and Performance Measurement, Journal of Political Economy, 100: 598614.

Baker, G., Jensen, M., and Murphy, K.J. (1988), Compensation and Incentives: Practise vs. Theory, Journal of Finance, 43: 593-616.

Bauer, T.K. (2004), High Performance Workplaces and Job Satisfaction: Evidence from Europe, RWI: Mitteilungen, 54/55(1): 57-85..

Blanchflower, D.G. and Oswald, A.J. (2004), Well-Being over time in Britain and the USA, Journal of Public Economics, 88: 1359-1386.

Booth, A. and Frank. J. (1999), Earnings, Productivity, and Performance-Related Pay, Journal of Labor Economics, 17(3): 447-463.

Brown, C. (1992), Wage Levels and Methods of Pay, The Rand Journal of Economics, 23(3): 366-375.

Brown, S. and Sessions, J.G. (2003), Attitudes, expectations and sharing, Labour, 17: 543 - 569.

Burgess, S. and Ratto, M. (2003), The Role of Incentives in the Public Sector: Issues and Evidence, Oxford Review of Economic Policy, 19: 285-300.

Chevalier, A. and Lydon, R. (2002) Estimates of the Effect of Wages on Job Satisfaction, CEP Discussion Papers Discussion Paper No. 0531, Centre for Economic Performance, LSE

Clark, A.E. (1999), Are wages habit-forming? Evidence from micro data, Journal of Economic Behaviour and Organization, 39: 179-200.

Clark, A. E. and Oswald, A.J. (1996), Satisfaction and Comparison Income, Journal of Public Economics, 61: 359 381.

Clark, A.E., Frijters, P. and Shields, M.A., (2008[a]). Relative Income, Happiness, and Utility: An Explanation for the Easterlin Paradox and Other Puzzles, Journal of Economic Literature, 46(1): 95-144.

Clark, A.E., Diener, E., Georgellis, Y. and Lucas, R.E. (2008[b]), Lags and Leads in Life Satisfaction: a Test of the Baseline Hypothesis, Economic Journal, 118(529): F222 - F243.

Clegg, C.W. (1983), Psychology of Employee Lateness, Absence and Turnover: Methodology, a Critique and an Empirical Study, Journal of Applied Psychology, 68: 88-101.

Deci, E. (1971), The Effects of Externally Mediated Rewards on Intrinsic Motivation, Journal of Personality and Social Psychology, 18(1): 105-115.

Deci, E. and Ryan. R.M. (1985), Intrinsic Motivation and Self-Determination in Human Behaviour, New York: Plenum Press.

Drago, R., Estrin, S. And Wooden, M. (1992), Pay for Performance Incentives and Work Attitudes, Australian Journal of Management, 17: 217-232.

EPICURUS, (2007). Societal and Economic Effects on Quality of Life and Well-being: Preference Identification and Priority Setting in Response to Changes in Labour Market Status, EU Research on Social Sciences and Humanities Report, No. EUR 23133, Belgium: European Communities.

Eriksson, T. and Villeval, M.C. (2008), Other-Regarding Preferences and Performance Pay - An Experiment on Incentives and Sorting, Journal of Economic Behaviour and Organization, 68: 412-421.

Falk, A., and Kosfeld, M. (2006), The Hidden Cost of Control, American Economic Review, 96(5): 1611-1630.

Fehr, E. and Gachter, S. (1998), Reciprocity and Economics: The Economic Implications of HomoReciprocans, European Economic Review, XLII: 845-859.

Ferrer-i-Carbonell, A. (2005), Income and well-being: an empirical analysis of the comparison income effect, Journal of Public Economics, 89(5-6): 997-1019.

Ferrer-i-Carbonell, A. and Fritjers, P. (2004), How important is methodology for the estimates of the determinants of happiness?, Economic Journal, 114: 641-659.

Festinger, L. (1957), A theory of cognitive dissonance, Evanston, IL: Row, Peterson.

Frank, R.H. and Hutchens, R.M. (1993), Wages, seniority, and the demand for rising consumption profiles, Journal of Economic Behavior and Organization, 21: 251-276.

Freeman, R.B. (1978), Job Satisfaction as an Economic Variable, The American Economic Review, 68(2): $135-141$.

Frey, B. (1997), Not Just for the Money: An Economic Theory of Personal Motivation, Cheltenham: Edward Elgar Publishing Limited.

Frey, B.S. and Jegen, R. (2001), Motivation Crowding Theory: A Survey of Empirical Evidence, Journal of Economic Surveys, 15(5): 589-611.

Frey, B. and Stutzer, A. (2002), What can Economists learn from Happiness Research?, Journal of Economic Literature, 40(2): 402-435.

Georgellis, Y., Gregoriou, A. and Tsitsianis, N. (2008), Adaptation towards reference values: A non-linear perspective Journal of Economic Behavior and Organization, 67: 768-781. 
Georgellis, Y. and Tabvuma, V. (2010), "Does public service motivation adapt”, Kyklos, forthcoming.

Gibbons, R. and Waldman, M. (1999), Careers in organizations: Theory and evidence, in: O. Ashenfelter \& D. Card ed., Handbook of Labor Economics, edition 1, vol. 3, chapter 36: Elsevier: 2373-2437.

Gneezy, U. (2004), The W effect of incentives, working paper of the Levins Bibliography of the UCLA Department of Economics.

Gneezy, U. and Rustichini, A. (2000[a]), Pay enough or don't pay at all, Quarterly Journal of Economics, Aug: 791810.

Gneezy, U. and Rustichini, A. (2000[b]), A fine is a price, Journal of Legal Studies, 29(1): 1-17.

Green, C. and Heywood, J.S. (2008), Performance Pay, Sorting and the Dimensions of Job Satisfaction, Economica, 75(300): 710-728.

Heckman, J.J. (1979), Sample selection bias as a specification error, Econometrica, 47: 153-61.

Heywood, J.S. and Wei, X. (2006), Performance Pay and Job Satisfaction, Journal of Industrial Relations, 48: 523 540.

Holmstrom, B. (1979), Moral hazard and observability, Bell Journal of Economics, 9: 74-91.

Holmstrom, B. (1982), Moral Hazard in Teams, Bell Journal of Economics, 13: 324-340.

Holmstrom, B. and Milgrom, P. (1991), Multitask principal-agent analyses: incentive contracts, asset ownership, and job design, Journal of Law, Economics, and Organization, 7: 24-52.

Horisch, H. and Strassmair, C. (2008), An experimental test of the deterrence hypothesis, Discussion paper of Department of Economics, University of Munich, February,

Judge, T. A., Bono, J. E., Thoresen, C. J., and Patton. G. K. (2001), The Job Satisfaction-Job Performance Relationship: A Qualitative and Quantitative Review, Psychological Bulletin, 127(3): 376-407.

Kohn, A. (1993), Punished By Rewards: The Trouble with Gold Stars, Incentive Plans, As, Praise, and Other Bribes, Boston: Houghton Mifflin.

Kreps, D.M. (1997), Intrinsic Motivation and Extrinsic Incentives, The American Economic Review, 87(2): $359-364$.

Lazear, E.P. (1986), Salaries and Piece Rates, Journal of Business, 59: 405-431.

Lazear, E.P. (2000), Performance Pay and Productivity, American Economic Review, 90(5): 1346-1361.

Lawler, E. and Porter, L. W. (1967), The effect of performance on job satisfaction, Industrial Relations, 7: 20-28.

Lawler, E.E. (1971), Pay and Organizational Effectiveness: A Psychological View. New York: McGraw-Hill.

Loewenstein, G. and Sicherman, N. (1991), Do workers prefer increasing wage profiles?, Journal of Labor Economics, 9: 67-84.

McKelvey, R. and Zavoina, W. (1975), A statistical model for the analysis of ordinal level dependent variables, Journal of Mathematical Sociology, 4: 103-120.

Marsden, D., French, S. and Kubo, K. (2001). Does performance pay de-motivate, and does it matter? Discussion Paper: 503, London School of Economics, Centre for Economic Performance.

Mas-Colell, A., Whinston, M.D., and Green, J.R. (1995), Microeconomic Theory, Oxford: Oxford University Press.

McCausland, W., Pouliakas, K. and Theodossiou, I. (2005), Some are punished and some are rewarded: A study of the impact of performance pay on job satisfaction, International Journal of Manpower, 26: 636-659.

Mirlees, J. (1976), The optimal structure of incentives and authority within an organization, Bell Journal of Economics, 7: 105-131.

Pokorny, K. (2008), Pay - but do not pay too much. An experimental study on the impact of incentives, Journal of Economic Behavior and Organization, 66: 251-264.

Pouliakas, K. and Theodossiou, I. (2009), Confronting Objections to Performance Pay: The Impact of Individual and Gain-sharing Incentives on Job Satisfaction, Scottish Journal of Political Economy, 56(5): 662-684.

Pouliakas, K. and Theodossiou, I. (2010), Measuring the Utility Cost of Temporary Employment Contracts Before Adaptation: A Conjoint Analysis Approach, Economica, forthcoming.

Parent, D. (1999), Methods of Pay and Earnings: A Longitudinal Analysis, Industrial and Labor Relations Review, 53(1): 71-86.

Prendergast, C. (1999), The Provision of Incentives in Firms, Journal of Economic Literature, 37(1): 7-63.

Seiler, E. (1984), Piece Rate vs. Time-Rate: The Effect of Incentives on Earnings, Review of Economics and Statistics, vol. 66, no. 3, pp. 363-376.

Van Praag, B.M.S., and Ferrer-i-Carbonell, A. (2004), Happiness Quantified: A Satisfaction Calculus Approach, Oxford: Oxford University Press.

Wooldridge, J.M. 2002, Econometric Analysis of Cross-Section and Panel Data, Cambridge, MA: M.I.T. Press. 


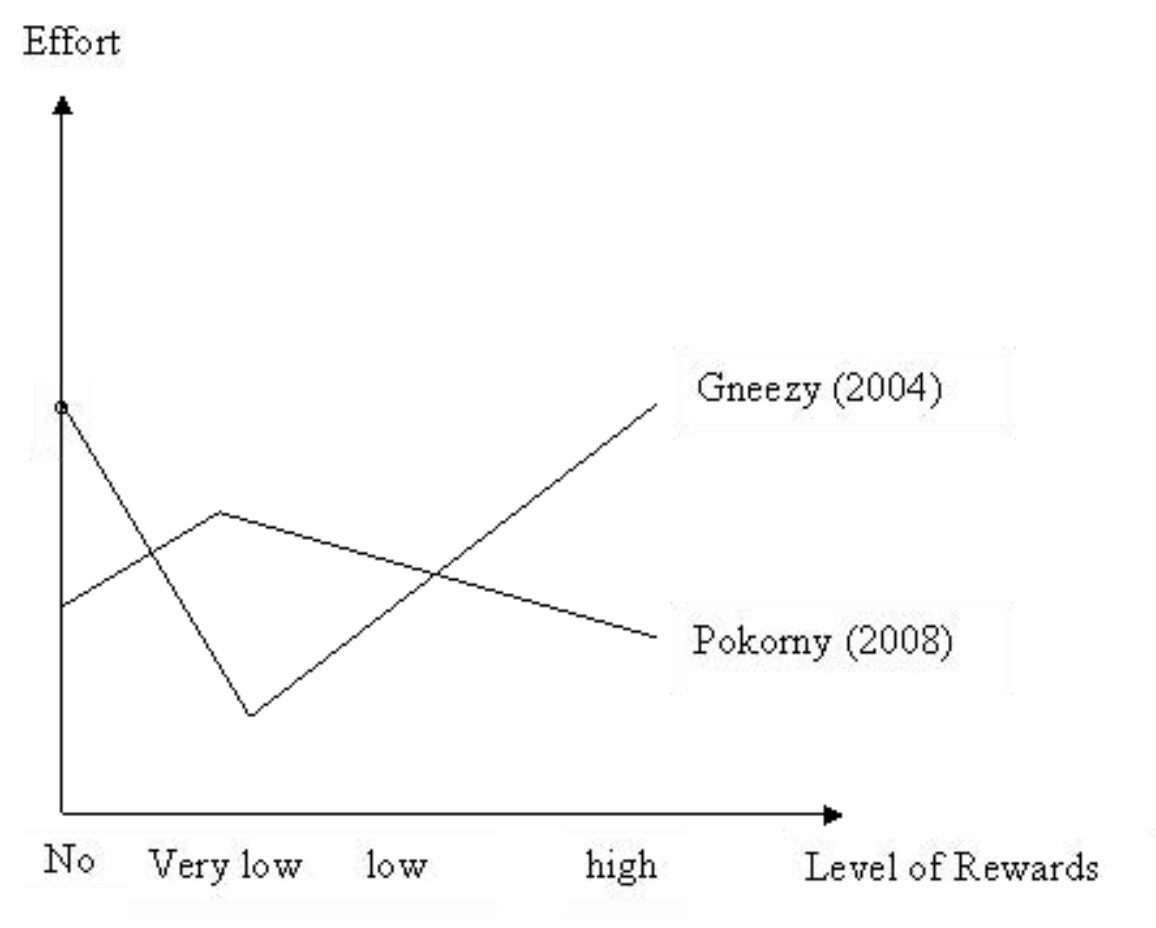

Figure 1 The effect of the level of incentives on effort

Table 1 Mean amount and intensity of annual gross bonus/profit-sharing by groups, BHPS, Employees, 1998-2007

\begin{tabular}{|l|c|c|c|}
\hline Gender & $\begin{array}{c}\text { (All) } \\
\text { Male }\end{array}$ & $\begin{array}{c}\text { Mean } \\
(\text { Bonus }>0)\end{array}$ & $\begin{array}{c}\text { Intensity } \\
\text { (Bonus }>\text { 0 })\end{array}$ \\
Female & 32189 & 2089.0 & 0.072 \\
Age & 35346 & 1126.5 & 0.059 \\
18-25 & 10202 & 902.6 & 0.055 \\
26-35 & 17702 & 1827.5 & 0.073 \\
$36 / 45$ & 18768 & 2037.5 & 0.072 \\
46/55 & 14375 & 1821.5 & 0.062 \\
56/65 & 6488 & 1105.6 & 0.053 \\
Partner & & & \\
Married & 48961 & 1835.8 & 0.070 \\
Single & 18552 & 1272.1 & 0.058 \\
Education & & & \\
Higher & 2627 & 3413.4 & 0.084 \\
First & 9946 & 3143.4 & 0.090 \\
Hnd, hnc, teach & 21606 & 1700.8 & 0.066 \\
A level & 8795 & 1596.6 & 0.070 \\
O level & 13289 & 1146.0 & 0.061 \\
Cse & 3227 & 832.0 & 0.047 \\
None & 6825 & 630.2 & 0.041 \\
PRP & & & \\
No & 58132 & 1408.4 & 0.057 \\
Yes & 9237 & 2414.2 & 0.091 \\
Contract & & & \\
\hline
\end{tabular}




\begin{tabular}{|c|c|c|c|}
\hline Temporary & 3196 & 882.4 & 0.056 \\
\hline Permanent & 64324 & 1697.4 & 0.067 \\
\hline \multicolumn{4}{|l|}{ Sector } \\
\hline Private & 44109 & 1789.1 & 0.070 \\
\hline Public & 19699 & 926.3 & 0.044 \\
\hline Other & 3721 & 825.1 & 0.042 \\
\hline \multicolumn{4}{|l|}{ Union } \\
\hline No & 31473 & 1904.2 & 0.071 \\
\hline Yes & 33940 & 1416.1 & 0.061 \\
\hline \multicolumn{4}{|l|}{ Hours status } \\
\hline Part-time & 13638 & 643.9 & 0.054 \\
\hline Full-time & 53650 & 1833.2 & 0.068 \\
\hline \multicolumn{4}{|l|}{ Firm Size } \\
\hline $1-25$ & 23,159 & 1489.5 & 0.069 \\
\hline $25-99$ & 17,979 & 1593.9 & 0.063 \\
\hline $100-499$ & 14,812 & 1681.6 & 0.063 \\
\hline $500+$ & 11,464 & 2117.4 & 0.072 \\
\hline \multicolumn{4}{|l|}{ Occupation } \\
\hline Managers and Administrators & 8764 & 3301.0 & 0.098 \\
\hline Professional Occupations & 6359 & 2555.4 & 0.074 \\
\hline Associate professional \& Technical & 7531 & 1983.7 & 0.069 \\
\hline Clerical \& Secretarial & 10463 & 903.4 & 0.062 \\
\hline Craft \& Related & 5628 & 1012.3 & 0.051 \\
\hline Personal and Protective Service & 7162 & 564.4 & 0.036 \\
\hline Sales & 4330 & 1514.5 & 0.076 \\
\hline Plant \& machine Operatives & 5031 & 786.4 & 0.041 \\
\hline Other & 4517 & 664.2 & 0.036 \\
\hline Total & 67,414 & 1684.1 & 0.067 \\
\hline
\end{tabular}

\begin{tabular}{|l|c|c|c|}
\hline \multicolumn{3}{|c|}{$\begin{array}{c}\text { Table 2 Mean (s.d.) job satisfaction scores by type of incentive status } \\
\text { and intensity, BHPS, Employees, 1998-2007 }\end{array}$} \\
\hline PRP & $N$ & Overall & s.d \\
No & 58101 & 5.38 & 1.27 \\
Yes & 9233 & 5.29 & 1.25 \\
Bonus & & & \\
No & 49996 & 5.37 & 1.28 \\
Yes & 17368 & 5.34 & 1.23 \\
Bonus Intensity & & & \\
$0 \%$ & 50163 & 5.37 & 1.28 \\
$<1 \%$ & 4390 & 5.33 & 1.27 \\
$1-3 \%$ & 4407 & 5.32 & 1.25 \\
$3-8 \%$ & 4215 & 5.34 & 1.21 \\
$8-25 \%$ & 3461 & 5.36 & 1.19 \\
$>25 \%$ & 863 & 5.47 & 1.20 \\
Change in bonus status & & & \\
No Bonus $\rightarrow$ No Bonus & 50,607 & 5.38 & 1.27 \\
No Bonus $\rightarrow$ Bonus & 4,266 & 5.33 & 1.26 \\
Bonus $\rightarrow$ No Bonus & 4,003 & 5.24 & 1.32 \\
Bonus $\rightarrow$ Bonus & 8,659 & 5.35 & 1.19 \\
\hline Total & 67535 & 5.37 & 1.27 \\
\hline
\end{tabular}


Table 3

Effect of Bonus Intensity on Job Satisfaction, BHPS, Employees, 1998-2007

\begin{tabular}{|c|c|c|c|c|c|}
\hline & (1) & (2) & (3) & (4) & (5) \\
\hline & $\begin{array}{l}\text { Ordered } \\
\text { Probit } \\
\text { (Whole } \\
\text { sample) }\end{array}$ & $\begin{array}{c}\text { ME Prob. } \\
(J S=7)\end{array}$ & $\begin{array}{c}\text { Fixed } \\
\text { Effects } \\
\text { (Sample } \\
\text { excluding } \\
\text { PRP) }\end{array}$ & $\begin{array}{l}\text { Heckman } \\
\text { (Bonus } \\
\text { sample) }\end{array}$ & $\begin{array}{c}\text { Ordered } \\
\text { Probit } \\
\text { (Bonus }+ \text { PRP } \\
\text { sample) }\end{array}$ \\
\hline $\begin{array}{l}\text { Bonus Intensity } \\
\text { Proportion (continuous variable) }\end{array}$ & $\begin{array}{c}0.530 * * * \\
(0.105)\end{array}$ & 0.087 & $\begin{array}{c}0.312 * * \\
(0.139)\end{array}$ & $\begin{array}{c}0.419 * * * \\
(0.136)\end{array}$ & $\begin{array}{c}0.382 * * * \\
(0.114)\end{array}$ \\
\hline \multicolumn{6}{|l|}{ Proportion (dummy variables) } \\
\hline$<1 \%$ & $\begin{array}{c}0.022 \\
(0.023)\end{array}$ & 0.004 & $\begin{array}{c}0.020 \\
(0.026)\end{array}$ & & $\begin{array}{l}-0.059 \\
(0.037)\end{array}$ \\
\hline $1-3 \%$ & $\begin{array}{l}0.038^{*} \\
(0.022)\end{array}$ & 0.006 & $\begin{array}{c}0.006 \\
(0.027)\end{array}$ & & $\begin{array}{l}-0.046 \\
(0.035)\end{array}$ \\
\hline $3-8 \%$ & $\begin{array}{c}0.061 * * * \\
(0.023)\end{array}$ & 0.010 & $\begin{array}{c}0.031 \\
(0.030)\end{array}$ & & $\begin{array}{l}-0.024 \\
(0.035)\end{array}$ \\
\hline $8-25 \%$ & $\begin{array}{c}0.074 * * * \\
(0.029)\end{array}$ & 0.013 & $\begin{array}{l}0.061 * \\
(0.037)\end{array}$ & & $\begin{array}{l}-0.017 \\
(0.039)\end{array}$ \\
\hline$>25 \%$ & $\begin{array}{c}0.225^{* * * *} \\
(0.048)\end{array}$ & 0.043 & $\begin{array}{c}0.149 * * \\
(0.069)\end{array}$ & & $\begin{array}{c}0.141 * * \\
(0.056)\end{array}$ \\
\hline PRP & $\begin{array}{c}-0.044 * * \\
(0.018)\end{array}$ & -0.007 & & & $\begin{array}{c}-0.099 * * * \\
(0.025)\end{array}$ \\
\hline Mills ratio & & & & $\begin{array}{l}-0.328 \\
(0.242) \\
\end{array}$ & $\begin{array}{l}-0.023 \\
(0.205)\end{array}$ \\
\hline $\begin{array}{l}\mathrm{N} \\
\text { Wald Test } \chi^{2}(F \text { in column } 3) \\
\text { Number of individuals }\end{array}$ & $\begin{array}{c}49317 \\
2463.02 * * *\end{array}$ & & $\begin{array}{c}43162 \\
22.81 * * * \\
10827\end{array}$ & $\begin{array}{c}9927 \\
1013.88 * * *\end{array}$ & $\begin{array}{c}16956 \\
1058.23 * * *\end{array}$ \\
\hline
\end{tabular}




\begin{tabular}{|c|c|c|c|c|}
\hline \multicolumn{5}{|c|}{$\begin{array}{l}\text { Table } 4 \\
\text { Fixed Effects Estimates of Bonus Intensity on Facets of Job Satisfaction, } \\
\text { BHPS, Employees, 1998-2007 }\end{array}$} \\
\hline & $\begin{array}{c}(1) \\
\text { Total Pay }\end{array}$ & $\begin{array}{c}(2) \\
\text { Job Security }\end{array}$ & $\begin{array}{c}\text { (3) } \\
\text { Work itself }\end{array}$ & $\begin{array}{c}(4) \\
\text { Hours }\end{array}$ \\
\hline \multirow{2}{*}{$\begin{array}{l}\text { Bonus } \\
\text { Intensity } \\
<1 \%\end{array}$} & & & & \\
\hline & $\begin{array}{c}0.047 \\
(0.030)\end{array}$ & $\begin{array}{c}0.072 * * \\
(0.028)\end{array}$ & $\begin{array}{l}-0.030 \\
(0.027)\end{array}$ & $\begin{array}{c}0.011 \\
(0.028)\end{array}$ \\
\hline $1-3 \%$ & $\begin{array}{c}0.045 \\
(0.030)\end{array}$ & $\begin{array}{l}0.049 * \\
(0.029)\end{array}$ & $\begin{array}{l}-0.045^{*} \\
(0.027)\end{array}$ & $\begin{array}{c}0.020 \\
(0.029)\end{array}$ \\
\hline $3-8 \%$ & $\begin{array}{c}0.104 * * * \\
(0.033)\end{array}$ & $\begin{array}{c}0.095 * * * \\
(0.032)\end{array}$ & $\begin{array}{l}-0.032 \\
(0.030)\end{array}$ & $\begin{array}{c}0.044 \\
(0.032)\end{array}$ \\
\hline $8-25 \%$ & $\begin{array}{c}0.189 * * * \\
(0.042)\end{array}$ & $\begin{array}{c}0.109 * * * \\
(0.041)\end{array}$ & $\begin{array}{l}-0.026 \\
(0.038)\end{array}$ & $\begin{array}{c}0.058 \\
(0.040)\end{array}$ \\
\hline$>25 \%$ & $\begin{array}{c}0.245^{* * * *} \\
(0.078)\end{array}$ & $\begin{array}{c}0.100 \\
(0.075)\end{array}$ & $\begin{array}{c}0.085 \\
(0.070)\end{array}$ & $\begin{array}{c}0.103 \\
(0.073)\end{array}$ \\
\hline Constant & $\begin{array}{c}4.603 * * * \\
(0.287)\end{array}$ & $\begin{array}{c}3.743 * * * \\
(0.278)\end{array}$ & $\begin{array}{c}5.778 * * * \\
(0.258) \\
\end{array}$ & $\begin{array}{c}6.955 * * * \\
(0.271) \\
\end{array}$ \\
\hline $\mathrm{N}$ & 43138 & 43019 & 43141 & 43176 \\
\hline $\begin{array}{l}\text { Number of } \\
\text { individuals }\end{array}$ & 10824 & 10800 & 10825 & 10830 \\
\hline $\mathrm{R}^{2}$ & 0.04 & 0.07 & 0.03 & 0.02 \\
\hline
\end{tabular}




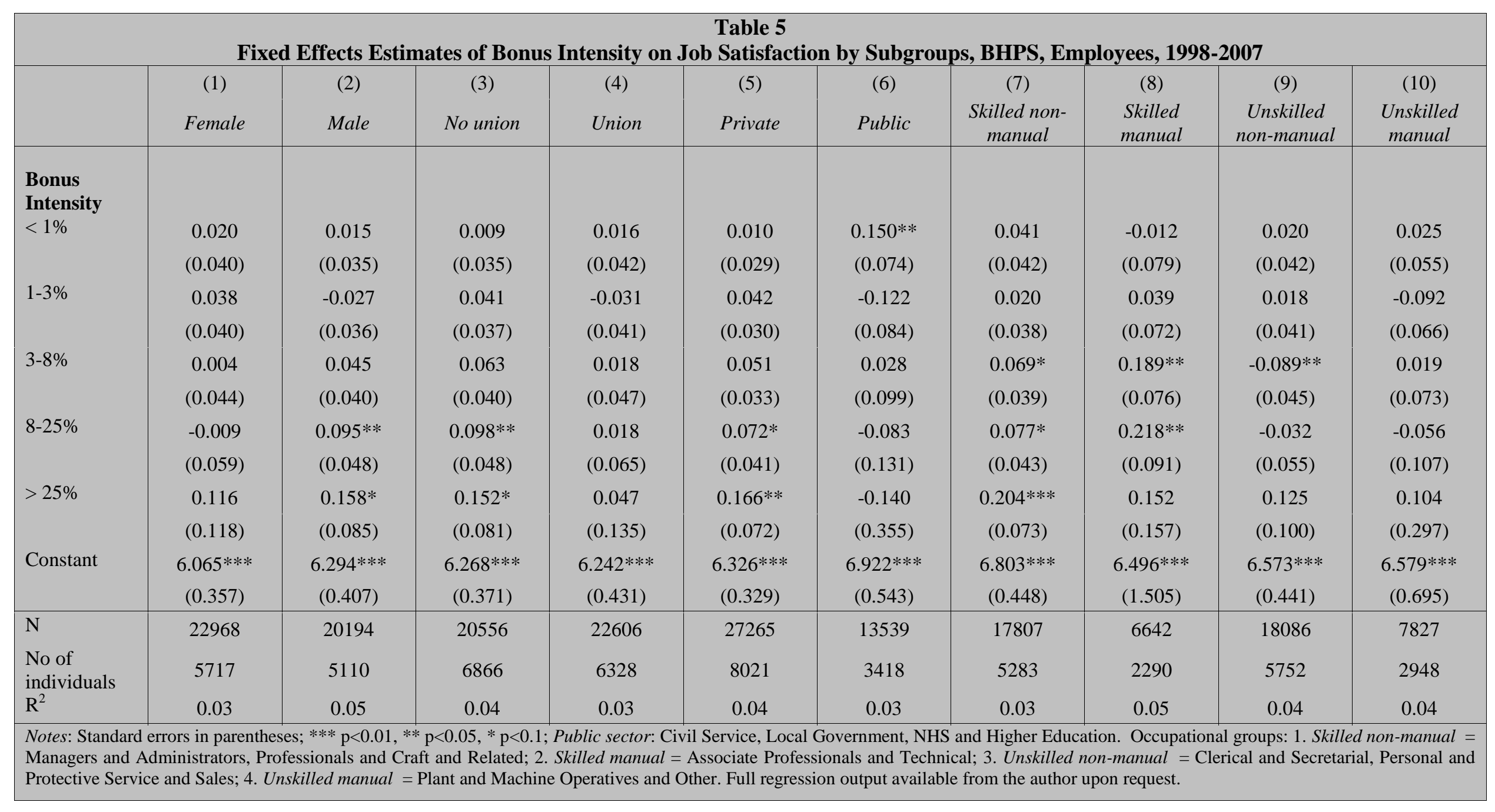




\begin{tabular}{|c|c|c|}
\hline \multicolumn{3}{|c|}{ 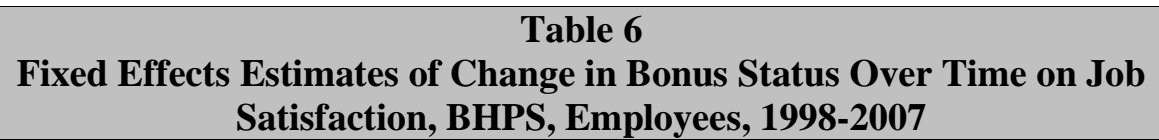 } \\
\hline & $\begin{array}{c}\text { (1) } \\
\text { Change }\end{array}$ & $\begin{array}{c}(2) \\
\text { Dynamics }\end{array}$ \\
\hline No Bonus $\rightarrow$ Bonus (1st year) & $\begin{array}{c}0.005 \\
(0.022)\end{array}$ & $\begin{array}{c}0.026 \\
(0.020)\end{array}$ \\
\hline Bonus $\rightarrow$ No Bonus & $\begin{array}{c}-0.071 * * * \\
(0.022)\end{array}$ & \\
\hline Bonus $\rightarrow$ Bonus & $\begin{array}{c}-0.046 * * \\
(0.020)\end{array}$ & \\
\hline Lag - Bonus for 2 years consecutively & & $\begin{array}{l}-0.017 \\
(0.024)\end{array}$ \\
\hline Lag - Bonus for 3 years consecutively & & $\begin{array}{l}-0.011 \\
(0.029)\end{array}$ \\
\hline Lag - Bonus for 4 years consecutively & & $\begin{array}{c}-0.071 * * \\
(0.036)\end{array}$ \\
\hline Lag - Bonus for 5 years consecutively & & $\begin{array}{l}-0.045 \\
(0.042)\end{array}$ \\
\hline Lag - Bonus > 5 years consecutively & & $\begin{array}{l}-0.047 \\
(0.050)\end{array}$ \\
\hline Constant & $\begin{array}{c}6.004 * * * \\
(0.732)\end{array}$ & $\begin{array}{c}5.814 * * * \\
(0.233)\end{array}$ \\
\hline $\mathrm{N}$ & 49317 & 50362 \\
\hline Number of individuals & 11237 & 11406 \\
\hline $\mathrm{R}^{2}$ & 0.04 & 0.04 \\
\hline
\end{tabular}




\begin{tabular}{|c|c|c|}
\hline \multicolumn{3}{|c|}{$\begin{array}{c}\text { Appendix Table A1 } \\
\text { Summary statistics of main variables, BHPS, Employees, 1998-2007 }\end{array}$} \\
\hline & Mean & $s d$ \\
\hline PRP & 0.137 & 0.344 \\
\hline Bonus & 0.258 & 0.437 \\
\hline \multicolumn{3}{|l|}{ Bonus Intensity } \\
\hline $0 \%$ & 0.743 & 0.437 \\
\hline$<1 \%$ & 0.065 & 0.247 \\
\hline $1-3 \%$ & 0.065 & 0.247 \\
\hline $3-8 \%$ & 0.062 & 0.242 \\
\hline $8-25 \%$ & 0.051 & 0.221 \\
\hline$>25 \%$ & 0.013 & 0.112 \\
\hline Gender & 0.477 & 0.499 \\
\hline Age & 38.947 & 11.650 \\
\hline Partner & 0.725 & 0.446 \\
\hline Ln (pay) & 1.767 & 0.535 \\
\hline Ln (hours) & 3.477 & 0.400 \\
\hline Permanent & 0.953 & 0.212 \\
\hline Time travel & 23.519 & 20.684 \\
\hline Annual increments & 0.481 & 0.500 \\
\hline Promotion opportunities & 0.505 & 0.500 \\
\hline Union & 0.519 & 0.500 \\
\hline Two Jobs & 0.083 & 0.276 \\
\hline Full-time & 0.797 & 0.402 \\
\hline Pension scheme & 0.731 & 0.443 \\
\hline Employer premises & 0.816 & 0.387 \\
\hline Household income & 36461.82 & 22725.11 \\
\hline \multicolumn{3}{|l|}{ Education } \\
\hline Higher & 0.040 & 0.195 \\
\hline First & 0.150 & 0.357 \\
\hline Hnd, hnc, teach & 0.326 & 0.469 \\
\hline A level & 0.133 & 0.339 \\
\hline O level & 0.200 & 0.400 \\
\hline Cse & 0.049 & 0.215 \\
\hline None & 0.103 & 0.304 \\
\hline \multicolumn{3}{|l|}{ Health } \\
\hline Excellent & 0.275 & 0.446 \\
\hline Good & 0.489 & 0.500 \\
\hline Fair & 0.185 & 0.388 \\
\hline Poor & 0.045 & 0.208 \\
\hline Very Poor & 0.006 & 0.080 \\
\hline \multicolumn{3}{|l|}{ Supervisory duties } \\
\hline Manager & 0.220 & 0.414 \\
\hline Foreman/supervisor & 0.150 & 0.357 \\
\hline None & 0.630 & 0.483 \\
\hline \multicolumn{3}{|l|}{ Sector } \\
\hline Private & 0.653 & 0.476 \\
\hline Civil Service & 0.046 & 0.210 \\
\hline Local Government & 0.157 & 0.364 \\
\hline NHS/Higher Edu & 0.089 & 0.284 \\
\hline Other & 0.019 & 0.138 \\
\hline Non-profit orgs. & 0.036 & 0.186 \\
\hline \multicolumn{3}{|l|}{ Firm size } \\
\hline $1-25 m$ & 0.344 & 0.475 \\
\hline $25-99$ & 0.267 & 0.442 \\
\hline $100-499$ & 0.220 & 0.414 \\
\hline $500+$ & 0.170 & 0.376 \\
\hline
\end{tabular}




\begin{tabular}{|c|c|c|c|c|c|}
\hline \multicolumn{6}{|c|}{$\begin{array}{c}\text { Appendix Table A2 } \\
\text { Sensitivity Analysis of Effect of Bonus Intensity on Job Satisfaction, BHPS, Employees, 1998- } \\
2007\end{array}$} \\
\hline & (1) & (2) & (3) & (4) & (5) \\
\hline & $\begin{array}{l}\text { Ordered Probit } \\
\quad \text { (Sample } \\
\text { excluding PRP) }\end{array}$ & $\begin{array}{l}\text { Ordered Probit } \\
\text { (2-digit } \\
\text { occupation) }\end{array}$ & $\begin{array}{l}\text { Ordered Probit } \\
\text { (Gross bonus } \\
\text { response only) }\end{array}$ & $\begin{array}{l}\text { Ordered Probit } \\
\text { (Relative bonus) }\end{array}$ & $\begin{array}{l}\text { Ordered Probit } \\
\text { (Regional } \\
\text { Unemployment) }\end{array}$ \\
\hline \multicolumn{6}{|l|}{ Bonus Intensity } \\
\hline$<1 \%$ & $\begin{array}{c}0.036 \\
(0.025)\end{array}$ & $\begin{array}{l}0.041^{*} \\
(0.025)\end{array}$ & $\begin{array}{c}0.017 \\
(0.029)\end{array}$ & $\begin{array}{c}0.037 \\
(0.025)\end{array}$ & $\begin{array}{c}0.026 \\
(0.025)\end{array}$ \\
\hline $1-3 \%$ & $\begin{array}{l}0.055^{* *} \\
(0.025)\end{array}$ & $\begin{array}{l}0.056^{* *} \\
(0.025)\end{array}$ & $\begin{array}{l}0.055^{* *} \\
(0.028)\end{array}$ & $\begin{array}{l}0.056^{* *} \\
(0.025)\end{array}$ & $\begin{array}{l}0.044 * \\
(0.026)\end{array}$ \\
\hline $3-8 \%$ & $\begin{array}{c}0.101 * * * \\
(0.026)\end{array}$ & $\begin{array}{c}0.103 * * * \\
(0.026)\end{array}$ & $\begin{array}{c}0.102 * * * \\
(0.030)\end{array}$ & $\begin{array}{c}0.103 * * * \\
(0.026)\end{array}$ & $\begin{array}{c}0.103 * * * \\
(0.027)\end{array}$ \\
\hline $8-25 \%$ & $\begin{array}{c}0.098 * * * \\
(0.034)\end{array}$ & $\begin{array}{c}0.096 * * * \\
(0.034)\end{array}$ & $\begin{array}{c}0.115 * * * \\
(0.038)\end{array}$ & $\begin{array}{c}0.104 * * * \\
(0.034)\end{array}$ & $\begin{array}{c}0.089 * * \\
(0.036)\end{array}$ \\
\hline$>25 \%$ & $\begin{array}{c}0.231 * * * \\
(0.058)\end{array}$ & $\begin{array}{c}0.214 * * * \\
(0.059)\end{array}$ & $\begin{array}{c}0.281 * * * \\
(0.069)\end{array}$ & $\begin{array}{c}0.248 * * * \\
(0.061)\end{array}$ & $\begin{array}{c}0.0242 * * * \\
(0.059)\end{array}$ \\
\hline Relative bonus & & & & $\begin{array}{l}-0.218 \\
(0.252)\end{array}$ & \\
\hline Regional Unem & & & & & $\begin{array}{l}-0.007 \\
(0.009)\end{array}$ \\
\hline $\mathrm{N}$ & 42288 & 42288 & 39588 & 42288 & 38196 \\
\hline$\chi^{2}$ Wald Test & $2250 * * *$ & $2430^{* * *}$ & $2167^{* * *}$ & $2251^{* * *}$ & $2079^{* * *}$ \\
\hline
\end{tabular}

\begin{tabular}{|c|c|c|c|c|}
\hline \multicolumn{5}{|c|}{$\begin{array}{c}\text { Appendix Table A3 } \\
\text { Effect of Control Variables on Job Satisfaction, BI }\end{array}$} \\
\hline & $\begin{array}{c}\text { (1) } \\
\text { Ordered Probit } \\
\text { (Whole Sample) }\end{array}$ & $\begin{array}{c}\text { (2) } \\
\text { Fixed Effects } \\
\text { (Sample excluding } \\
\text { PRP) }\end{array}$ & $\begin{array}{c}\text { (3) } \\
\text { Heckman Outcome } \\
\text { Equation } \\
\text { (Bonus Sample) }\end{array}$ & $\begin{array}{c}\text { (4) } \\
\text { Selection Equation } \\
\operatorname{Pr}(B=1) \text { (Sample } \\
\text { excluding PRP) }\end{array}$ \\
\hline $\begin{array}{l}\text { Demographic } \\
\text { Male }\end{array}$ & $\begin{array}{c}-0.137 * * * \\
(0.018)\end{array}$ & & $\begin{array}{c}-0.158 * * * \\
(0.031)\end{array}$ & $\begin{array}{c}0.061 * * * \\
(0.017)\end{array}$ \\
\hline Age & $\begin{array}{c}-0.023 * * * \\
(0.005)\end{array}$ & $\begin{array}{l}-0.002 \\
(0.009)\end{array}$ & $\begin{array}{r}-0.015^{*} \\
(0.008)\end{array}$ & $\begin{array}{c}0.015^{* * *} \\
(0.004)\end{array}$ \\
\hline Age square & $\begin{array}{c}0.000 * * * \\
(0.000)\end{array}$ & $\begin{array}{c}0.000 \\
(0.000)\end{array}$ & $\begin{array}{c}0.000 * * \\
(0.000)\end{array}$ & $\begin{array}{c}-0.000 * * * \\
(0.000)\end{array}$ \\
\hline Partner & $\begin{array}{c}0.087 * * * \\
(0.017)\end{array}$ & $\begin{array}{l}0.000 \\
(0.027)\end{array}$ & $\begin{array}{c}0.066^{* *} \\
(0.030)\end{array}$ & $\begin{array}{c}0.026 \\
(0.017)\end{array}$ \\
\hline $\begin{array}{l}\text { Education } \\
\text { (Omitted: No qualif) }\end{array}$ & & & & \\
\hline Higher degree & $\begin{array}{c}-0.300 * * * \\
(0.046)\end{array}$ & & $\begin{array}{r}-0.157 * \\
(0.087)\end{array}$ & $\begin{array}{l}-0.038 \\
(0.048)\end{array}$ \\
\hline First degree & $\begin{array}{c}-0.265^{* * * *} \\
(0.034)\end{array}$ & & $\begin{array}{c}-0.237 * * * \\
(0.055)\end{array}$ & $\begin{array}{c}0.015 \\
(0.031)\end{array}$ \\
\hline Hnd, hnc, teaching & $-0.199 * * *$ & & -0.029 & -0.020 \\
\hline
\end{tabular}




\begin{tabular}{|c|c|c|c|c|}
\hline & $(0.036)$ & & $(0.058)$ & $(0.033)$ \\
\hline A-level & $\begin{array}{c}-0.184 * * * \\
(0.030)\end{array}$ & & $\begin{array}{c}-0.189 * * * \\
(0.050)\end{array}$ & $\begin{array}{c}0.134 * * * \\
(0.025)\end{array}$ \\
\hline O-level & $\begin{array}{c}-0.100 * * * \\
(0.028)\end{array}$ & & $\begin{array}{l}-0.033 \\
(0.047)\end{array}$ & $\begin{array}{c}0.128 * * * * \\
(0.023)\end{array}$ \\
\hline Cse & $\begin{array}{l}-0.055 \\
(0.041)\end{array}$ & & $\begin{array}{c}0.063 \\
(0.060)\end{array}$ & $\begin{array}{c}0.096^{* * *} \\
(0.033)\end{array}$ \\
\hline \multicolumn{5}{|l|}{$\begin{array}{l}\text { Health status } \\
\text { (Omitted: very poor) }\end{array}$} \\
\hline Excellent & $\begin{array}{c}0.370 * * * \\
(0.079)\end{array}$ & $\begin{array}{c}0.424 * * * \\
(0.078)\end{array}$ & $\begin{array}{c}0.816 * * * \\
(0.179)\end{array}$ & $\begin{array}{l}0.174^{*} \\
(0.094)\end{array}$ \\
\hline Good & $\begin{array}{c}0.160 * * \\
(0.078)\end{array}$ & $\begin{array}{c}0.308 * * * \\
(0.077)\end{array}$ & $\begin{array}{c}0.606 * * * \\
(0.178)\end{array}$ & $\begin{array}{l}0.175^{*} \\
(0.094)\end{array}$ \\
\hline Fair & $\begin{array}{c}0.001 \\
(0.078)\end{array}$ & $\begin{array}{c}0.190 * * \\
(0.077)\end{array}$ & $\begin{array}{c}0.458^{* *} \\
(0.179)\end{array}$ & $\begin{array}{l}0.173^{*} \\
(0.094)\end{array}$ \\
\hline Poor & $\begin{array}{l}-0.071 \\
(0.080)\end{array}$ & $\begin{array}{c}0.087 \\
(0.078)\end{array}$ & $\begin{array}{l}0.319^{*} \\
(0.185)\end{array}$ & $\begin{array}{c}0.146 \\
(0.099)\end{array}$ \\
\hline Household income & $\begin{array}{l}0.001 * * \\
(0.000)\end{array}$ & $\begin{array}{l}-0.000 \\
(0.000)\end{array}$ & $\begin{array}{c}0.002 * * * \\
(0.001)\end{array}$ & $\begin{array}{c}0.001 * * * \\
(0.000)\end{array}$ \\
\hline \multicolumn{5}{|l|}{$\begin{array}{l}\text { Financial situation: } \\
\text { Change last year } \\
\text { (Omitted: better off) }\end{array}$} \\
\hline Worse off & $\begin{array}{c}-0.340 * * * \\
(0.016)\end{array}$ & $\begin{array}{c}-0.260 * * * \\
(0.018)\end{array}$ & $\begin{array}{c}-0.356 * * * \\
(0.039)\end{array}$ & $\begin{array}{c}-0.102 * * * \\
(0.020)\end{array}$ \\
\hline About same & $\begin{array}{c}-0.154 * * * \\
(0.012)\end{array}$ & $\begin{array}{c}-0.144 * * * \\
(0.014)\end{array}$ & $\begin{array}{c}-0.112 * * * \\
(0.029)\end{array}$ & $\begin{array}{c}-0.055^{* * *} \\
(0.016)\end{array}$ \\
\hline \multicolumn{5}{|l|}{$\begin{array}{l}\text { Financial } \\
\text { expectations next } \\
\text { year } \\
\text { (Omitted: better) }\end{array}$} \\
\hline Worse & $\begin{array}{c}-0.209 * * * \\
(0.022)\end{array}$ & $\begin{array}{c}-0.161 * * * \\
(0.025)\end{array}$ & $\begin{array}{c}-0.242 * * * \\
(0.049)\end{array}$ & $\begin{array}{c}0.046 \\
(0.028)\end{array}$ \\
\hline Same & $\begin{array}{c}0.007 \\
(0.013)\end{array}$ & $\begin{array}{l}-0.008 \\
(0.014)\end{array}$ & $\begin{array}{c}0.010 \\
(0.027)\end{array}$ & $\begin{array}{l}0.029^{*} \\
(0.016)\end{array}$ \\
\hline Job-related & & & & \\
\hline Ln (hours) & $\begin{array}{c}-0.203 * * * \\
(0.033)\end{array}$ & $\begin{array}{c}-0.206 * * * \\
(0.036)\end{array}$ & $\begin{array}{c}-0.291 * * * \\
(0.072)\end{array}$ & $\begin{array}{c}0.074 * * \\
(0.037)\end{array}$ \\
\hline Permanent contract & $\begin{array}{c}0.131 * * * \\
(0.030)\end{array}$ & $\begin{array}{c}0.053 \\
(0.035)\end{array}$ & $\begin{array}{c}0.185 \\
(0.150)\end{array}$ & $\begin{array}{c}0.510 * * * \\
(0.051)\end{array}$ \\
\hline Travel to work time & $\begin{array}{c}-0.001 * * * \\
(0.000)\end{array}$ & $\begin{array}{c}0.000 \\
(0.000)\end{array}$ & $\begin{array}{l}-0.001 \\
(0.001)\end{array}$ & $\begin{array}{l}0.000 \\
(0.000)\end{array}$ \\
\hline $\begin{array}{l}\text { Annual increments } \\
\text { in pay }\end{array}$ & $\begin{array}{c}0.127 * * * \\
(0.013)\end{array}$ & $\begin{array}{c}0.132 * * * \\
(0.015)\end{array}$ & $\begin{array}{c}0.123 * * * \\
(0.025)\end{array}$ & $\begin{array}{l}0.008 \\
(0.015)\end{array}$ \\
\hline $\begin{array}{l}\text { Promotion } \\
\text { opportunities }\end{array}$ & $\begin{array}{c}0.208^{* * *} \\
(0.014)\end{array}$ & $\begin{array}{c}0.276 * * * \\
(0.016)\end{array}$ & $\begin{array}{c}0.232 * * * \\
(0.027)\end{array}$ & $\begin{array}{l}0.022 \\
(0.015)\end{array}$ \\
\hline $\begin{array}{l}\text { Trade union at } \\
\text { workplace }\end{array}$ & $-0.112 * * *$ & 0.009 & $-0.088^{* *}$ & $-0.119 * * *$ \\
\hline Second job & $\begin{array}{l}(0.018) \\
-0.029 \\
(0.024)\end{array}$ & $\begin{array}{c}(0.022) \\
-0.061 * * \\
(0.027)\end{array}$ & $\begin{array}{c}(0.036) \\
0.002 \\
(0.049)\end{array}$ & $\begin{array}{l}(0.017) \\
-0.013 \\
(0.027)\end{array}$ \\
\hline $\begin{array}{l}\text { Full-time (> 30 } \\
\text { hours per week) }\end{array}$ & $\begin{array}{c}-0.090 * * * \\
(0.030)\end{array}$ & $\begin{array}{c}-0.071 * * \\
(0.032)\end{array}$ & $\begin{array}{l}-0.118^{*} \\
(0.062)\end{array}$ & $\begin{array}{c}0.037 \\
(0.034)\end{array}$ \\
\hline $\begin{array}{l}\text { Employer runs } \\
\text { pension scheme }\end{array}$ & $-0.048 * *$ & -0.012 & $-0.123 * *$ & $0.245^{* * *}$ \\
\hline Work at employer's & $\begin{array}{c}(0.019) \\
-0.057 * * *\end{array}$ & $\begin{array}{c}(0.021) \\
-0.064 * *\end{array}$ & $\begin{array}{l}(0.054) \\
-0.049\end{array}$ & $\begin{array}{c}(0.019) \\
0.024\end{array}$ \\
\hline
\end{tabular}




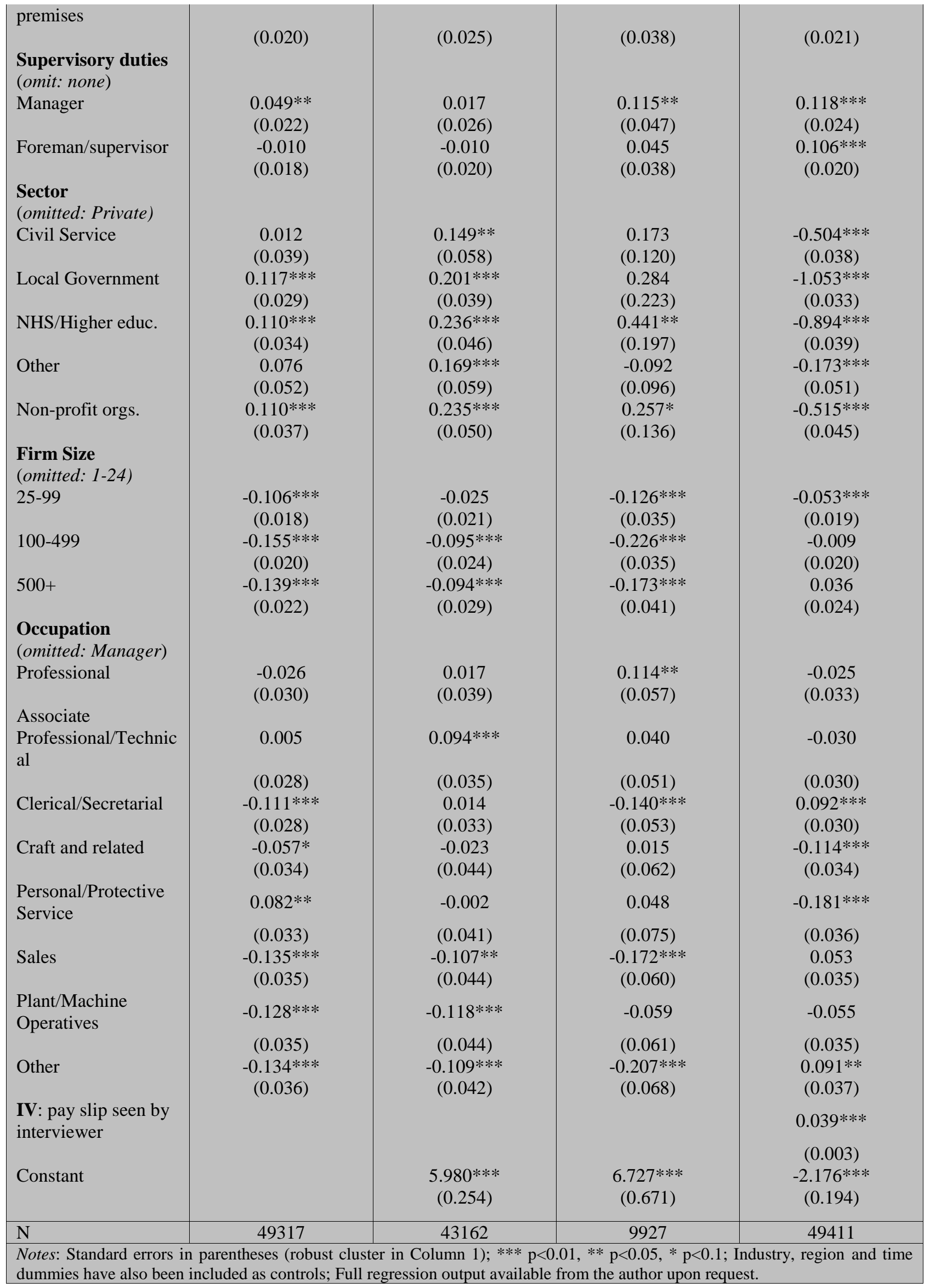




\section{Endnotes}

${ }^{1}$ Gneezy's (2004) W-effect refers to the effect of the provision of both positive (bonuses) and negative (fines) incentives on worker performance, as depicted in a 4-quadrant diagram. However, as the focus of this paper is on the provision of positive incentives only, as measured by the amount of bonuses received, it is therefore more accurate to speak of the "V-effect".

${ }^{2}$ As noted by Prendergast (1999, p. 7), these modes of furnishing employee effort vary widely across different organizations, with some firms relying on explicit contracts that tie pay to observable measures of (individual or aggregate) performance (piece rates, stock options, bonuses, profit sharing), others preferring reward systems that are based on more discretionary subjective measures of productivity, and some eschewing the use of pay-for-performance altogether in favour of alternative (dynamic) strategies (promotions, efficiency wages, deferred compensation, career concerns etc.).

${ }^{3}$ Indeed, empirical evidence suggests that even after controlling for the sorting effects of variable pay, the mean wages of workers earning part (or all) of their income due to explicit incentives are higher than of those who are paid according to time rates (Seiler, 1984; Brown, 1992; Booth and Frank, 1999; Parent, 1999; Lazear, 2000).

${ }^{4}$ This is consistent with empirical evidence suggesting that human beings may receive pleasure from wage increases per se, as they consistently favour upward-sloping earnings profiles even if their present discounted value is lower than that of flatter profiles (Loewenstein and Sicherman, 1991; Frank and Hutchens, 1993).

${ }^{5}$ The first experiment involved a group of university students who were offered different marginal payoffs for giving correct answers to an IQ test, while in the second the group of interest were high-school students doing volunteer work by collecting donations for charitable organizations. A related field study was also carried out by Gneezy and Rustichini (2000[b]) emphasizing the effect of penalties, such as fines for late arrivals of parents collecting their children in Israeli day-care centres. In contradiction to the deterrence hypothesis, according to which one would expect to observe a reduction in a sanctioned behaviour, the effect that was observed was an increase in the number of late-coming parents after the imposition of the fine. Interestingly, once the fine was removed no reduction occurred in the number of late arrivals, thus suggesting that changing perceptions, once realized, are hard to reverse. The deterrence hypothesis has also been recently rejected by the neutrally framed laboratory experiment of Horisch and Strassmair (2008), who test whether crime is weakly decreasing in the probability and severity of punishment. Allowing for subjects to steal from another participant's payoff, they show that except for very high levels of incentives, subjects steal more the stronger the incentives. They also observe that this effect depends on whether the subjects are selfish or fairminded, with the former complying with the predictions of agency theory and deterrent incentives backfiring for the latter.

6 "Of course, the question of what is a high reward or fine is case-dependent" (Gneezy, 2004, p. 8). As argued by Gneezy and Rustichini (2000, p. 805), not all small compensations may be insulting, neither are insulting compensations necessarily small.

${ }^{7}$ Respondents were asked "Does your pay ever include incentive bonuses or profit related pay?" from the first year of the survey (1991), although the definition of the question was altered in 1996.

${ }^{8}$ The Pearson correlation coefficient between the bonus and the PRP questions is 0.24 . Specifically, only $7.2 \%$ of the sample receive both types of incentive compensation simultaneously, while $6.5 \%$ are recipients of individual PRP only and $18.6 \%$ of bonuses/profit-sharing pay only. The remaining percentage $(67.7 \%)$ receives no form of performance-contingent pay.

${ }^{9}$ The questions regarding the facets of promotion prospects, relations with boss, and the use of initiative were discontinued after the 7 th wave.

${ }^{10}$ The influence of the remaining covariates, apart from those of incentive intensity, is in accordance with the predictions of previous research (Frey and Stutzer, 2002).

${ }^{11}$ In order to facilitate estimation of equation (6), a linear probability model is assumed, since dealing with fixed effects when the dependent variable (JS) is ordinal can be problematic. Moreover, Ferrer-i-Carbonell and Fritjers (2004) conclude that although the inclusion of panel individual effects is important for the estimation of subjective well-being models, adopting the assumption of cardinality for the satisfaction responses does not make much of a difference. As a robustness check, equation (6) has also been estimated using an appropriate linearization of the ordinal JS variable based on the so-called Probit OLS (POLS) approach (van Praag and Ferrer-i-Carbonell, 2004), which replaces JS using a 'conditional mean' approximation that takes into consideration the frequency distribution of the variable. No significant differences in the results are found (available upon request from the author).

${ }^{12}$ A quadratic Proportion term has also been entered into the specification in order to examine whether there are any non-linearities in the effect of incentive intensity on job satisfaction, but this variable was found to have an insignificant influence. 